\title{
Urban versus conventional agriculture, taxonomy of resource profiles: a review
}

\author{
Benjamin Goldstein ${ }^{1}$ (D) $\cdot$ Michael Hauschild ${ }^{2} \cdot$ John Fernández $^{3} \cdot$ Morten Birkved $^{4}$
}

Accepted: 21 December 2015 / Published online: 20 January 2016

(C) INRA and Springer-Verlag France 2016

\begin{abstract}
Urban agriculture appears to be a means to combat the environmental pressure of increasing urbanization and food demand. However, there is hitherto limited knowledge of the efficiency and scaling up of practices of urban farming. Here, we review the claims on urban agriculture's comparative performance relative to conventional food production. Our main findings are as follows: (1) benefits, such as reduced embodied greenhouse gases, urban heat island reduction, and storm water mitigation, have strong support in current literature. (2) Other benefits such as food waste minimization and ecological footprint reduction require further exploration. (3) Urban agriculture benefits to both food supply chains and urban ecosystems vary considerably with system type. To facilitate the comparison of urban agriculture systems we propose a classification based on (1) conditioning of the growing space and (2) the level of integration with buildings. Lastly, we compare the predicted environmental performance of the four main types of urban agriculture that arise through the
\end{abstract}

Benjamin Goldstein

bgol@dtu.dk

1 Quantitative Sustainability Assessment Division Producktionstorvet, Technical University of Denmark, Building 424, Room 225,

Kongens Lyngby 2800, Denmark

2 Quantitative Sustainability Assessment Division Producktionstorvet, Technical University of Denmark, Building 424, Room 209, Kongens Lyngby 2800, Denmark

3 Department of Architecture, Massachusetts Institute of Technology, 77 Massachusetts Avenue, 5-419, Cambridge, MA 02139, USA

4 Quantitative Sustainability Assessment Division, Technical University of Denmark, Producktionstorvet, Building 424, Room 216, Kongens Lyngby 2800, Denmark application of the taxonomy. The findings show how taxonomy can aid future research on the intersection of urban food production and the larger material and energy regimes of cities (the "urban metabolism").

Keywords Urban agriculture · Quantitative sustainability assessment · Urban food systems · Life cycle assessment . Building integrated agriculture $\cdot$ Urban metabolism $\cdot$ Industrial ecology

Contents

1. Introduction

2. Environmental performance of urban agriculturedisaggregating claims and evidence

2.1 Building energy

2.2 Urban symbiosis

2.3 Supply chain efficiencies

2.4 In situ environmental improvement

2.5 Ex situ environmental improvement

2.6 Urban agriculture-where do we stand?

3. Developing a taxonomy of urban agriculture

3.1 Building integration

3.2 Space conditioning

3.3 Urban agriculture types

3.4 Predicted attributes of urban agriculture types

3.4.1 Ground-based-non-conditioned systems

3.4.2 Ground-based-conditioned systems

3.4.3 Building-integrated-non-conditioned systems

3.4.4 Building-integrated-conditioned systems

4. Future directions in assessing urban agriculture

4.1 Application to studies of urban systems

4.2 Shortcomings of the proposed taxonomy

5. Conclusion

6. References 


\section{Introduction}

Recent scientific consensus is that humanity is skirting the planet's safe boundaries to sustainably supply resources to and assimilate society's waste (Krausmann et al. 2009; Steffen et al. 2015). As centers of population and economic activity, cities have a dominant influence on the scale and form of anthropogenic material and energy flows, consequently playing a central role in any shifts towards sustainability (Dearing et al. 2014; Pincetl et al. 2014). Hitherto, the general tenor in promoting urban sustainability has been a focus on minimizing fossil fuel intensive transport, reducing the energy consumption of buildings, and shifting cities towards renewable energy sources (Grubler et al. 2012; IPCC 2014a). These transitions are all important pieces in the sustainable urban development mosaic, but they disregard one of the largest environmental pressures of cities: urban food consumption. Supplying food to cities is one of the key contributors to greenhouse gas (GHG) emissions, biodiversity loss, water pollution, land-use change, non-renewable resource exhaustion, and a host of other pressing environmental challenges at the global scale (Foley et al. 2011; Tilman et al. 2011; Gliessman 2015). Therefore, transitions towards sustainable urban systems must include the mitigation of environmental impacts from urban food consumption.

Multiple angles exist to address the environmental burden of urban food demands. Internalizing environmental burdens of food production within prices using Pigovian taxes has been suggested to nudge consumers away from environmentally burdensome foods (e.g., meat and dairy) (Edjabou and Smed 2013). Others have emphasized transitions to diets that combine seasonality of local food production, selectively consume organic, and contain reduced animal protein (Saxe 2014). Another option at the demand side is to reduce food waste in cities, lowering gross urban food demands and solid waste burdens (FAO 2013). Cities have also banned certain types of food packaging (see New York City's sanction against polystyrene) to reduce the environmental impacts of the food system at this end (Stringer 2015). Conversely, supply side interventions promote eco-efficiency gains within existing production systems (e.g., reducing fertilizer per unit economic output) (Tilman et al. 2011; Davis et al. 2012).

\subsection{Urban agriculture to promote environmental sustainability}

While the bulk of food production is exogenous to the city, urban agriculture (UA) has been touted as a supplyside urban design intervention that can give cities agency over the environmental performance of some of their food demands (Pearson et al. 2010; Hampwaye 2013; IPCC 2014b). Though many definitions exist (see Vejre's outlining of the spatial, functional, market, and other dimensions of defining UA; Vejre 2012), the most salient features are that is consists of food production in and around cities, weaving this practice within the urban form, such that it interacts with the host city's material and energy metabolism (Koc et al. 1999).

Recent estimates peg urban farmers at $25-30 \%$ of global urban dwellers (Orsini et al. 2013). Most of these practitioners operate in emerging economies as an informal means of income and subsistence (Smit et al. 2001); however, there has been increasing interest in intensifying and formalizing UA globally as part of a more sustainable and resilient global food system (Pearson et al. 2010). Very optimistic estimates assert that UA could supply $100 \%$ of global urban vegetable needs with $40 \%$ of urban land at current yields (Martellozzo et al. 2014), while others have estimated that UA already produces $15-20 \%$ global food (Abdulkadir et al. 2012). Shanghai and Beijing stand out as examples in that their metropolitan regions supply the majority of their produce (Lee-Smith and Prain 2006) and Shanghai most of its dairy demands (Orsini et al. 2013). The potential in post-industrial cities is believed to be high but untapped (Grewal and Grewal 2012; Taylor and Lovell 2012; Haberman et al. 2014); rooftop UA could provide $77 \%$ of Bologna's vegetable needs (Orsini et al. 2014) or $36 \%$ of Singapore's vegetable intake (Astee and Kishnani 2010). Other assessments are less optimistic, such as Oakland's potential to supply between 0.6 and $1.5 \%$ of recommended vegetable needs (McClintock et al. 2013). A the institutional level, a departure from the farming-antagonistic land-use planning that dominated the twentieth century (Brunori and Di Iacovo 2014) towards active promotion by cities (City of Boston 2014; Five Borough Farm 2014) punctuates a new narrative, supporting the re-integration of food production within the contemporary city.

\subsection{Urban agriculture's environmental performance}

Large-scale implementation of UA within cities may be a vital step towards improving urban environmental performance, but many claims of UA's improved environmental sustainability relative to conventional agricultural remain premature given the paucity of field verification and quantitative sustainability assessment (QSA) of UA systems (Pearson et al. 2010; Pataki et al. 2011; Specht et al. 2013). To date, much of the discourse around UA's environmental potential focuses on its ability to reduce distance from farm to fork, ignoring how such systems may be maladaptive when other aspects of urban food production are considered (e.g., warming greenhouses in northern climes to avoid transport from southern countries) (Born 
and Purcell 2006). Recent QSAs have begun to address the gaps in knowledge surrounding UA's environmental performance. Sanyé-Mengual's and colleagues' studies of urban rooftop greenhouses showed these systems can provide tomatoes with lower embodied environmental burdens relative to traditional supply chains $(2012,2015 b)$. On the other hand, Kulak et al. (2013) reduced climate change impacts for UA in London relative to conventional supply chains for some produce, but not others.

These initial environmental evaluations of UA simultaneously provide answers and raise questions. SanyéMengual et al.'s work on soil-less rooftop UA revealed major differences in environmental performance between the different cultivation methods $(2015 \mathrm{c})$. If there are noticeable differences in environmental performance between cropping systems on a single rooftop, how large are the differences between UA systems with fundamentally dissimilar characteristics (integrated with buildings vs. grown on land) and are there general trends in environmental performance between these types of systems? Kulak et al. (2013) found that capital inputs for low-tech greenhouses deleteriously affected the environmental performance of UA in London. If modest inputs are influential, how do these inputs affect the performance of UA systems with markedly contrasting material needs (raised beds vs. greenhouses) and are there general performance trends between UA types? Lastly, there has been only tangential discussion about how large-scale UA would influence citywide material and energy fluxes (its "urban metabolism") if it were scaled up within a given city (Pataki et al. 2011; Cerón-Palma 2012).

The propensity to consider single UA types out of the multitude that exist (greenhouse, raised-beds, vacant lot, etc.) overlooks the non-trivial energy and material profiles of different UA systems, leaving an incomplete picture of UA's environmental strengths and weaknesses. As a result, it remains unclear whether installing different forms of agricultural production forms en masse in cities across the globe constitute a net reduction in food related environmental impacts from cities, necessitating a holistic and systematic look at UA's environmental performance. If there were patterns of environmental performance for different types of UA, the development of a heuristic to support future research and urban design decisions would be of utility to academics, policy makers, and UA champions alike. To date, such a system has been lacking, with previous work in cataloguing UA centered around social and economic concerns (Jacobi et al. 2000; Smit et al. 2001; Brock and Foeken 2006; Dossa et al. 2011; Orsini et al. 2013; Thomaier et al. 2015). Moreover, researchers of urban environmental performance without an agricultural background (e.g., industrial ecologists, urban planners, landscape urbanists, etc.) lack a tool to organize and assimilate the environmental performance of UA within their own assessments of the larger urban environment.

\subsection{Study goal and scope}

This article consolidates and expands on earlier reviews of UA's environmental sustainability (Pearson et al. 2010; Pataki et al. 2011; Specht et al. 2013) with an updated appraisal of the myriad environmental claims surrounding UA and their existing levels of support. We then distill these findings into an UA taxonomy based on UA system material use, energy consumption, and interaction with the built form. This taxonomy will provide an organizing framework for future QSA research and deliver clarity to non-agronomists. Through a focus on those aspects of UA most salient to researchers of urban environmental performance, the taxonomy will also act as a device to scale up from studies of environmentally sustainable at the individual UA project level to assessments of food production networks at the city scale.

\section{Environmental performance of urban agriculture - disaggregating claims and evidence}

Using the aforementioned literature reviews as a point of departure, both peer-reviewed and grey literature were perused throughout 2014 and 2015. The reviewed material illuminated a patchwork of qualitative and quantitative environmental declarations surrounding UA. Table 1 presents these claims along with any support across five umbrella terms that encompass them: building energy, urban symbiosis, supply chain efficiencies, in situ and ex situ environmental improvements.

\subsection{Building energy}

The potential benefits of UA in relation to building energy consumption are some of the best documented due to previous research on green roofing that can reasonably be extrapolated into the realm of UA. UA is posited to reduce building energy in a number of ways:

1. Passive methods - increasing building albedo (light reflection), endothermic plant/substrate evapotranspiration (Qiu et al. 2013) or improving building insulation (Smit et al. 2001);

2. Active methods - cooling building space with evaporative cooling in greenhouse (Ackerman 2012) or exchanging excess heat between building and greenhouse to reducing building energy needs (Cerón-Palma 2012).

Field trials of green roofs in Canada and China support the passive benefits along with a model of green roofs in the USA (Bass and Baskaran 2003; Kokogiannakis et al. 2011; Jaffal et al. 2012). Conversely, increasing accessible roof area significantly diminished life cycle energy savings (16 to $4 \%$ ) for green roofs in Singapore (Wong et al. 2003), a challenge 
Table 1 Summary of sustainability claims and quantitative support surrounding urban agriculture

Sustainability claim
Building energy
Heating load reduction (Smit et al. 2001)
Cooling load reduction (IBID; Ackerman 2012;
RUAF 2006)
RUAF 2006)

\author{
Urban symbiosis \\ Nutrient capture and recycling (RUAF 2006; \\ Mougeot 1994; Specht et al. 2013)
}

Rainwater capture and use (Havaligi 2011;

Despommier 2013)

Excess building heat utilization (Ackerman 2012)

\author{
Supply chain efficiencies \\ Reduced food-miles (Knowd and Mason 2006; \\ Ackerman 2012; Specht et al. 2013) \\ Improved yields (Smit et al. 2001; Despommier 2013; \\ Besthorn 2013) \\ Reduced food waste (Sanyé-Mengual et al. \\ 2012, 2015b) \\ Reduced packaging (IBID)

\section{In situ ecosystem improvement} \\ Improved biodiversity (Knowd and Mason 2006; \\ Havaligi 2011) \\ Urban heat island attenuation (Pearson et al. 2010; \\ Wong et al. 2003)
}

Stormwater attenuation (Ackerman 2012; Sida 2003)

Soil quality (Smit et al. 2001; Jansson 2013)

Air quality improvement (Hampwaye 2013)

Ex situ ecosystem improvement

Carbon sequestration (Sida 2003; Despommier 2013)

Carbon footprint reduction (IBID)

Lower ecological footprint (RUAF 2006)

Improved biodiversity (same as above)

Soil quality (same as above)
Support

- Green roofs on Chinese buildings appreciably reduced heating loads, benefits diminished with building insulation (Kokogiannakis et al. 2011) ${ }^{\mathrm{a}}$

- Green roofs found to be beneficial in cold European climates (Jaffal et al. 2012)

- $41 \%$ heating energy reduction modeled with rooftop urban agriculture in northern climate (Delor 2011)

- $5 \%$ reduction through insulation, $79 \%$ reduction through air exchange from rooftop greenhouse in Mediterranean environment (Cerón-Palma 2012)

- Modeled $23 \%$ cooling reduction with rooftop greenhouse in Toronto, CA (Bass and Baskaran 2003) $)^{\mathrm{a}}$

- Indoor temperature and annual building energy reduced by $2{ }^{\circ} \mathrm{C}$ and $6 \%$, respectively (Jaffal et al. 2012)

- Life cycle building energy for diminished from $16 \%$ in extensive to $4 \%$ in intensive green roofs (Wong et al. 2003)

- Wastewater recycling performed in African (Ruma and Sheikh 2010), Asian urban agriculture (Khai et al. 2007) a and 1800s Paris (Barles 2007)

- Compost application to urban agriculture in Cuba (Hernandez et al. 2014) and UK (Edmondson et al. 2014) $)^{\mathrm{a}}$

- Rooftop farm in Paris utilized local food waste to generate a compost substrate (Grard et al. 2015) ${ }^{\mathrm{a}}$

- Osmosis filtration and rainwater capture satisfied water needs of greenhouse in Manhattan, USA (Nelkin and Caplow 2008) ${ }^{\mathrm{a}}$

- Hypothetical stormwater farm outside of Melbourne, AU had numerous benefits to local water management (Liebman et al. 2011)

- Fertilecity rooftop greenhouse in Barcelona, ES collects rainwater for irrigation reducing water impacts by $98 \%$ compared to conventional tomato production (Sanyé-Mengual et al. 2015b) ${ }^{\mathrm{a}}$

- Modeled urban greenhouse showed potential benefits of using air from host building for heat in Barcelona, ES (Sanyé-Mengual et al. 2015b)

- Lufa Greenhouses in Montreal, CA utilizes energy of site building for heating ${ }^{\mathrm{a}}$

- Local production around Osaka, JP reduced embodied energy in vegetables by $25 \%$ (Hara et al. 2013)

- Urban greenhouse in NL provided improved yields above traditional agricultural for numerous products (Besthorn 2013) ${ }^{\mathrm{a}}$

- Assumed $17 \%$ reduction in food losses over distribution (Sanyé-Mengual et al. 2012)

- Packaging savings potentially reduce carbon footprint with urban agriculture in Barcelona, ES (Sanyé-Mengual et al. 2012, 2015b)

- Green roofs shown to increase local biodiversity (Hoffman 2007; Oberndorfer et al. 2007; Forman 2014)

- Satellite models showed appreciable UHI reduction in New York City, USA, with hypothetical urban agriculture scenario (Ackerman 2012)

- $50 \%$ green roof cover could reduce ambient temperatures by $2{ }^{\circ} \mathrm{C}$ in Toronto (Bass and Baskaran 2003)

- Significantly slower runoff rate and runoff retention observed at green roofs around North America (Oberndorfer et al. 2007) $^{\mathrm{a}}$

- Green roof significantly mitigated runoff in Mediterranean (Fioretti et al. 2010) ${ }^{\mathrm{a}}$

- Compost on UK urban agriculture improved soil structure and nutrients (Edmondson et al. 2014)

- Models linked urban forest cover in China (Jim and Chen 2009) and green roofs in Chicago (Yang et al. 2008) with reduced local $\mathrm{NO} x, \mathrm{SO} x, \mathrm{O}_{3}$, and particulates

- Urban green infrastructure in Toronto, CA and Salt Lake City, USA, sequestered $<1 \%$ of urban CF (Kennedy 2012; Pataki et al. 2009)

- Significant greenhouse gas reduction for urban agriculture except for polytunnel strawberries (Kulak et al. 2013)

- Rooftop greenhouse tomatoes in Barcelona showed lower embodied carbon than conventional supply chain from $33 \%$ (Sanyé-Mengual et al. 2015b) to $63 \%$ (Sanyé-Mengual et al. 2012)

- None encountered

- None encountered

- None encountered

${ }^{\mathrm{a}}$ A field trial 
considering UA operations require space for maintenance, harvesting, packaging, etc. Looking at rooftop greenhouses, a US analysis showed that potential to cool the host building is present, but in a diminished capacity compared to standard green roofs, also due to light-absorbing maintenance areas (Delor 2011) with Cerón-Palma modeling annual energy savings from insulation at less than $5 \%$ in a Mediterranean climate (2012). Climate was also important, with green roofs reducing summer indoor temperatures in Stockholm and Athens, lowering winter heating load in Stockholm through insulation, but increasing winter heating load in Athens due to evapotranspiration (Jaffal et al. 2012). Moreover, these benefits to building energy diminish when well-insulated buildings considered (Castleton et al. 2010; La Roche and Berardi 2014).

Less explored are UA's active benefits. Cerón-Palma (2012) integration of the energy systems of a rooftop greenhouse and an office building in a Mediterranean climate, showing that heat recovery from the greenhouse using ventilation could reduce indoor heating requirements by $79 \%$, though it should be considered that heating requirements in the Mediterranean are already relatively low.

\subsection{Urban symbiosis}

Urban symbiosis is UA's potential to leverage proximate urban residual material and energy fluxes as production factors, attenuating urban waste and avoiding virgin material inputs to food production. Three dominant claims emerged:

1. Waste assimilation - the use of waste with high organic carbon or nutrient content to supplement UA substrate or nutrient demands (Grewal and Grewal 2012);

2. Rainwater harvesting - reducing runoff to sewers and reducing irrigation demands (Nelkin and Caplow 2008);

3. Building energy - utilizing excess building energy to reduce greenhouse energy inputs (Cerón-Palma 2012).

Waste assimilation is a recurring claim, since cities import large amounts of synthetically produced nutrients embedded within food that usually end up in waste streams for emission to local water bodies (Morée et al. 2013) or partial recovery during waste management (Larsen et al. 2001; Kalmykova et al. 2012). UA could act as a sink for nutrient-rich greywater (baths and sinks), blackwater (toilets), and organic solid waste (household, commercial, or industrial), providing the basis for a closed-loop urban food production system (Grewal and Grewal 2012).

In practice, cities have leveraged black-water for UA historically (Barles 2007) and in present day emerging economies (Qadir et al. 2010; Forman 2014), though the public health risks from pathogens and heavy metals remain high (Cofie et al. 2006; Qadir et al. 2010). Nutrients are also captured downstream at wastewater treatment plants where sewage sludge is pelletized to fertilize animal feed or energy crops (skirting the issue of direct human pathogen consumption) (Miljøministreriet 2005), largely excluding usage in UA.

Two forms of organic solid waste are available to generate nutrient-rich compost in cities: food scraps and yard detritus. Food scraps have long been utilized in UA with recent examples being in Cuba (Hernandez et al. 2014), the UK (Edmondson et al. 2014), and New York City (City of New York 2014), though policy makers in the latter have actively fought against implementing household organic waste collection due to perceived costs (Decker et al. 2000). A rooftop, raised-bed farm in Paris used $100 \%$ local organic waste fractions (food waste, coffee grounds, and mycelium, crushed wood, wood chips, and potting soil) as a substrate, producing lettuce in yields comparable to commercial operations (Grard et al. 2015). Yard refuse-derived compost is actively distributed to UA sites by New York City (City of New York 2014). Although composting reduces pathogen-related health risks, potential contamination from heavy metals remains challenging (Hargreaves et al. 2008), while carbon-nitrogen ratios of the different waste streams must also be considered to maintain soil health and productivity (Komilis et al. 2012; Awasthi et al. 2015). The aforementioned UA project in Paris is a positive example in this regard, getting $100 \%$ of nutrient demands through a balanced waste blend, while producing food in line with EU food safety standards (Grard et al. 2015).

Other urban symbiosis potentials include rainwater harvesting and excess building energy capture. The former has been implemented (Nelkin and Caplow 2008), with over 100 operations in New York City utilizing this practice (Cohen et al. 2012), though risks exist for rain to deliver airborne contaminants acidifying the soil or depositing heavy metals (Forman 2014). Rainwater collection has also been seen in rooftop greenhouses, such as the Fertilecity project in Barcelona, ES reducing water impacts by $98 \%$ compared to a traditional tomato (Sanyé-Mengual et al. 2015b), the Arbor House in New York City (Green Home NYC 2011), and Lufa Farms in Montreal, CA (Lufa Farms 2014). Benefits of rainwater capture must be balanced against the embodied burdens additional structural buttressing, which can be significant depending on the installed system, and pumping energy requirements. Angrill et al. (2012) found that rainwater harvesting for nonpotable use reduced local water demands, but had higher global warming impacts compared to municipal water supply in some instances. It remains unknown how these tradeoffs influence the overall performance of rooftop farms. Excess building energy can be used to moderate growing space temperature; therefore, it is only of utility to greenhouse systems and, though conceptually sound, lacks application. Cerón-Palma (2012) modeled using excess building energy as a means to warm a rooftop greenhouse, finding that periods of greenhouse heating demand were misaligned with periods of excess building heat over diurnal cycles, precluding use of the this energy. 


\subsection{Supply chain efficiencies}

Efficient supply chains are the streamlined needs of UA compared to typical urban food supply chains. Claims in this regard appear to focus on three points:

1. Reduced "food-miles"- shorter distance between producing and consumer (Born and Purcell 2006);

2. Increased yields - improved farm performance over conventional supply chains (Despommier 2013);

3. Distribution efficiencies - reduced packaging and spoilage (Sanyé-Mengual et al. 2012).

By reducing the distance from producer to market ("foodmiles") environmental sustainability claims relating to transport naturally arise, which at first glance appears defensible assuming a priori that food grown within a city is consumed locally. Notwithstanding, the focus on "food-miles" may be misplaced, due to transport's relatively small environmental impacts over food supply chains (Born and Purcell 2006; Edwards-Jones et al. 2008), except where air transport or long distance refrigerated freight occurs (FAO 2011a). A model of local vegetable production around Osaka found that local vegetable production could reduce $25 \%$ of food production energy (Hara et al. 2013), lending credence to "food-miles." However, energy is not a holistic indicator for environmental performance since increased impacts in other aspects of production could erase reductions in transport energy ("burden shifting").

The efficiency claim of improved yields of UA greenhouses, achieved by shielding crops from moderating variables (pests, extreme weather, etc.) is true for all greenhouses (von Zabeltitz 2011) and is not a unique benefit of UA. This claim may be justified in the context of vertical farms (stacked greenhouses), since they produce more food per unit area, such as the Mirai project in Japan which produces 10,000 lettuce heads a day with under $2500 \mathrm{~m}^{2}$ (Dickie 2014). Vertical farms (or "plant factories") continue to proliferate with examples in South Korean (Suwon Farm), the Netherlands (PlantLab), and the USA (Green Spirit Farms) (Marks 2014), though it remains unknown whether the increased yields offset the potentially high capital and energy requirements of these systems. At the other end of the spectrum, low-tech UA systems in sub-Saharan Africa had poor practices and profligate pesticide usage well above recommended rates, leading to yields below conventional supply chains and increased public health risks (Perrin et al. 2015).

Lastly, analyses of rooftop greenhouses posit that UA could reduce both packaging and food waste (Sanyé-Mengual et al. 2012, 2015b). The former is a logical consequence of lower food-miles and is potentially important in reducing selected environmental impacts (IBID). Food waste is more complex since it is primarily generated at the retailer and consumer in wealthy populations, versus at the farm or in transit in poorer countries (FAO 2011b), meaning that UA could better reduce losses in a developing context. Notwithstanding, if earlier assessments are correct, food losses might be reduced by UA relative to the conventional supply chain.

\subsection{In situ environmental improvement}

In situ environmental improvement outlines beneficial environmental amenities brought to the urban environment by UA. From the literature review, the following claims were identified:

1. Increased biodiversity (Havaligi 2011);

2. Reduced urban heat island (UHI) - lower temperatures due to increased albedo and evapotranspiration (Oberndorfer et al. 2007);

3. Reduced stormwater runoff-retention by substrate and filtering of pollutants (IBID);

4. Soil improvements - improved stability, organic carbon content (Jansson 2013);

5. Air quality - filtration of airborne pollution by plant matter (Hampwaye 2013).

Claims regarding UA's improvement of local biodiversity are supported by experiments with vegetated roofs where polycropping (multiple crop species) and predatory pest control (e.g., ladybugs) were used (Hoffman 2007; Oberndorfer et al. 2007), but could be reversed if mono-culture cropping were implemented (Reidsma et al. 2006). UA is believed to provide refuge for keystone pollinators (e.g., bees), further enhancing urban ecosystem resilience through promoting functional diversity (IBID) and may provide green corridors for animal movement through cities when linked to larger parks systems (Forman 2014).

Two areas where the local environmental benefits of UA are well documented are UHI and urban runoff attenuation (Oberndorfer et al. 2007). UHI results from the propensity of low-albedo dark surfaces to trap solar radiation and transform it to heat, which UA mitigates by substituting these surfaces with plants that absorb sunlight for photosynthesis and provide shade ( $\mathrm{Li}$ et al. 2014), a benefit that will reap dividends with the increasing frequency of heat waves (Jansson 2013). UA substrates retain stormwater runoff for plant uptake or provide climate change adaptation by buffering the surges to local water systems (IBID). Moreover, ground-based UA opens a permeable hydraulic-bridge between stormwater and groundwater systems attenuating sewer systems stressed by the prevalence of impermeable surfaces in cities (Oberndorfer et al. 2007). These benefits are dependent on the UA form practiced, with shallow soil beds on green roofs reducing the attenuation UHI and stormwater (deep substrate green roofs can become waterlogged, eliminating runoff retention) (Luckett 2009), while greenhouses without rainwater 
capture have little benefits towards urban runoff management. Moreover, UA in low-lying areas of the cities may be inundated with polluted runoff from adjacent impermeable surfaces (Forman 2014). A negative consequence of UA is that runoff from urban farms may contain high nutrient loads that could exceed local assimilative capacity if these systems are scaled up within cities (Emilsson et al. 2007; Li and Babcock 2014).

For the soil quality claims, UA must be planted in local soils (eliminating most greenhouses from this benefit) and the soils must avoid the contamination common in cities (Meuser 2010; Li and Babcock 2014). With these conditions met, UA may improve soil stability and fertility, contingent on harnessing ecological principles to maintain organic carbon and nutrient levels (Gliessman 2015), as demonstrated in some British allotment gardens (Edmondson et al. 2014). Lastly, air quality improvements have been seen in a number of models of green areas in cities (Yang et al. 2008; Jim and Chen 2009), though the potential for numerous plant species to emit toxic compounds when stressed (Pataki et al. 2011) requires more attention.

\subsection{Ex situ environmental improvement}

Ex situ environmental improvement relates to benefits conferred by UA beyond the city region. In the reviewed material, the following claims were identified:

1. Carbon sequestration - removal and storage of $\mathrm{CO}_{2}$ from the atmosphere (Sida 2003);

2. Reduced carbon footprint-lower embodied greenhouse gas emissions for production and distribution of food compared to conventional supply chains (IBID);

3. Reduced ecological footprint - lower agricultural land occupation for consumers (RUAF 2006);

4. Improved biodiversity - return of marginal agricultural land to nature (Knowd and Mason 2006);

5. Improved soil quality - return of marginal agricultural land to nature (Smit et al. 2001).

The first is that of the carbon sequestration, whereby UA fixates atmospheric carbon through photosynthesis. Li and Babcock's (2014) review of green roofs carbon sequestration highlighted the potential for this type of infrastructure to accumulate biomass. Notwithstanding the claim's veracity, UA's true contribution towards carbon sequestration may ultimately be marginal, as shown by studies of Toronto, CA (a city with considerable foliage) (Kennedy 2012) and Salt Lake City, USA (Pataki et al. 2009) where the urban tree canopy sequestered $<1 \%$ of urban carbon dioxide emissions.

For carbon footprint assessments of rooftop greenhouse tomato production in Barcelona, ES showed 33-62 \% reduction in embodied carbon impacts relative to conventional supply chains, a result of the reduced transport, packaging, and predicted food distribution losses (Sanyé-Mengual et al. 2012, 2015b). An assessment of food produced in London allotment gardens revealed significant embodied carbon reductions (25-99 \%) for fruits in vegetables (Kulak et al. 2013). UA performed worse for strawberries grown in lowtech greenhouses, showing that UA's benefits hinged on low material intensity methods producing local foods, or the substitution of high-impact foods with UA (e.g., foods air freighted to the UK). Comparing carbon sequestration of typical urban landscaping projects (parks and forests) to reduced climate change impacts from UA, consumption of UA has a greater impact per unit-cultivated area (IBID). Research has also shown that crop choice is an important aspect of greenhouse gas emissions, with high-yield fruits and vegetables (tomatoes, eggplants) having superior performance to lowyield leafy vegetables (Sanyé-Mengual et al. 2015c).

The other three extended environment assertions of improving biodiversity, soil quality, and the ecological footprint of cities remain difficult to prove or disprove. They appear predicated on the assumption that UA will displace farming outside of cities, allowing succession of agricultural land to mature ecosystems, a shaky contention in a globalized world with increasingly affluence, growing population (Foley et al. 2011; World Bank 2013) and limited options to expand conventional agricultural production areas (FAO 2006). However, if UA were to play a larger role in global food production, it may stymie the conversion of natural habitats and even allow for conversion of farmland back to natural ecosystems, with the added benefit of sequestering carbon within soil and mature habitat.

\subsection{Urban agriculture—where do we stand?}

The literature revealed a muddled picture of UA's ability to reduce the environmental impacts from urban food demands and positively contribute to the urban ecosystem. Some claims are demonstrated to varying degrees (urban stormwater management, building energy use reductions, UHI, local biodiversity, nutrient recycling and soil quality, carbon footprint reduction), others prematurely (carbon sequestration, improved yields, air quality), while a few are of more speculative nature (EF reduction, soil upgrading outside the city, biodiversity gains, avoided food waste). UA could provide some of the more conjectural benefits, but there currently remains little proof-of-concept of those gains, meaning that conclusions about UA's general environmental efficacy are a priori.

What is clear is that UA's capability to increase the sustainability of urban food systems is contextual, based on UA method, product, and location. The case study of carbon sequestration in London, UK, allotment gardens exhibited all of these traits, with changing conclusions for different UA types growing the same product, since UA type dictated the 
supporting infrastructure (structure, HVAC, etc.) and operating inputs (chemicals, water, energy, etc.) (Kulak et al. 2013). Kulak et al. (2013) found that switching from outdoor to polytunnel strawberries reversed carbon footprint reductions over conventional production ( -53 to $+12 \%$ compared to base case). Interestingly, tomatoes did not show the same behavior, with significant embodied carbon reductions over conventional supply chains using outdoor or polytunnel methods. Recent assessments of rooftop soil-less production in Barcelona, ES also showed how environmental impacts for different growing techniques can vary for production on the same roof (Sanyé-Mengual et al. 2015c), with soil-less production methods of leafy greens having significantly superior environmental performance compared to soil-cultivated counterparts. Performance on local environmental indicators (UHI, stormwater retention, etc.) also varies according to UA scheme, highlighting that the relationship of UA to the larger urban ecology also depends on the UA type employed.

At the urban scale, it remains unknown how some of the benefits and shortcomings of UA might affect the greater urban system. Nutrient runoff from UA has been studied at the individual farm level, but the effects of the aggregate runoff from urban-scale UA implementation are not known. UA benefits of waste assimilation and UHI mitigation are also minimally understood at the city level.

\section{Developing a taxonomy to support the environmental assessment of $\mathrm{UA}$}

It has already been voiced by several researchers that further QSAs of UA are required before the environmental sustainability claims of UA champions can be verified (Ackerman 2012; Specht et al. 2013). Notwithstanding the need for more assessments, such explorations would be most effective with an organizing framework, such as a systematics of UA types based on environmental performance.

Kostrowicki started his 1977 definition of agricultural typologies with,

An attempt at ordering the investigated facts and/or processes according to a certain system is a characteristic stage of development of any scientific discipline. (Kostrowicki 1977)

This paper is not proposing anything as ambitious as a scientific discipline, but we do aim to provide a heuristic, in the form of a UA taxonomic scheme to order existing knowledge and future assessments of the environmental performance of UA. A taxonomic scheme (systematics, taxonomy, and typology are used interchangeably hereafter) is a grouping of individuals in a population based on the similarity of their attributes (e.g., organic, conventional, and biodynamic agriculture). This grouping does not ignore the uniqueness of the individuals (e.g., mono- and polycrop organic), but focuses on essential characteristics (e.g., organic prescribes no synthetic fertilizers or pesticides) to make a complicated reality comprehensible. It is for this reason that typologies are also hierarchical in nature, with sub-typologies belonging to higher order typologies (Kostrowicki 1977).

To date, taxonomies of UA have had a valence towards cataloguing based on socio-economic criteria (see Brock and Foeken 2006; Dossa et al. 2011; Drechsel and Dongus 2009; Jacobi et al. 2000; Smit et al. 2001). The social and economic aspects of UA are essential aspects of sustainability, but systematics framed around these attributes do not provide a clear picture to researchers or decision makers about the environmental performance of different UA types.

The aim of the systematics introduced here is to provide a simple, overarching scheme of the different combinations of essential attributes of UA that have important influences on the environmental dimensions of urban food production. At the base of it, the environmental performance of any production system hinges on the energy and material regime that supports the good or service it generates (Smil 2013). In agriculture, it is the production factors (fertilizers, land, fossil fuel energy, pesticides, irrigation, farming structures, and mechanized equipment) that influence the environmental burdens of food system (Davis et al. 2010; Roy et al. 2012; Meier and Christen 2013) and, in less frequently, transport (FAO 2011a). Our endeavor is to identify the broad characteristics of UA systems these capital inputs.

Considering the limited number of studies of UA's material and energy demands, a first impression of these was gathered from earlier assessments of isolated UA systems (Wong et al. 2003; Astee and Kishnani 2010; Sanyé-Mengual et al. 2012; 2015b; Kulak et al. 2013) as well as green roof (Luckett 2009), greenhouse (von Zabeltitz 2011), and UA (Philips 2013) design books. To support the literature findings, we visited UA operations and performed interviews urban farmers in Northeastern USA during the spring and summer of 2015. From these, we identified two organizing principles emerged that strongly influence UA energy and material regimes, forming the basis of the typology: building integration and space conditioning.

\subsection{Building integration}

The first organizing principle is how physically embedded the UA form is within the built environment. Designs that leverage residual UM flows (nutrients, building heat, etc.) are at an advantage to avoid/share virgin resource inputs over less immersed UA forms. For optimal access to residual UM flows and to potentially have direct energy exchange with buildings, UA is best situated on buildings where waste flows emerge and conditioned space is able to act as a source and/or sink for 
energy. This is most applicable to heat, which due to its dispersive nature, requires direct coupling of the UA and building energy systems in order to share excess energy (attenuating temperatures of growing and occupied space). Moreover, attaching UA to the built environment also insulates the host building, reducing building energy consumption. This intimate coupling can also bring benefits through the circulation of $\mathrm{CO}_{2}$-rich building exhaust into the greenhouse to promote growing (Sanyé-Mengual et al. 2014). The advantages of direct placement on buildings is less vital for nutrients, since nutrient-rich waste can potentially be collected at any place between point of generation and place of disposal for application as greywater, blackwater, compost, or other form, though proximity to generation points could be beneficial (IBID). Moreover, soil-based UA is best suited for urban nutrient recycling, since composting of solid organic waste is the commonest recycling method, though examples of application of waste-derived liquid growth stimulator may also be viable (Hernandez et al. 2014). Rainwater harvesting is not dependent on building integration. Because of these observations, we introduce building integrated and ground-based UA types, where the former is merged with existing building structures, while the latter occurs directly on the ground in a manner physically disconnected from surrounding buildings.

\subsection{Space conditioning}

The second consideration was the degree of interaction between UA systems and ambient environment. UA systems with conditioned growing spaces (e.g., greenhouses) allow year-round operation, capture and more efficiently recycle resources, minimize weather-related crop losses, and reduce pest invasion in contrast to open systems (e.g., vacant lot farming). Conversely, conditioned UA types also require large resource inputs in terms of building components, mechanical equipment, and embodied energy within capital equipment. Energy for space conditioning (light and temperature) is also paramount as the environmental performance of food production systems in some indicators (fossil fuel consumption, global warming forcing) are dependent on whether the conditioned space is heated or not (Stoessel et al. 2012). Non- conditioned systems contrast with this in that they usually have higher losses of resources to the ambient environment, but are less capital intensive, and have lower direct operational energy inputs. Non-conditioned systems also have higher risks of being negatively affected by local pollution (Antisari et al. 2015) and contributing to local pollution (Emilsson et al. 2007). The result being that these two classes of UA could have markedly different environmental performance. Therefore, we introduce the notions of conditioned and nonconditioned UA, where the former is quasi-closed system and the latter exposed to the elements.

\subsection{Urban agriculture types}

Because building integration and conditioning are not mutually exclusive, we derived four overarching UA types: ground-based-non-conditioned, ground-based-conditioned, building-integrated-non-conditioned, and building-integrated-conditioned. As mentioned above, the taxonomy is a simple tool for a rough organization of findings, so it does not describe the minutia of different sub-types. For instance, the building-integrated-conditioned could encompasses rooftop greenhouses and vertical farms, since they both are integrated within the built environment, have substantial capital inputs, and use large amounts of operational energy; all important factors that will differentiate their resource regimes and environmental impacts from a farm on an empty lot (groundbased-non-conditioned). Figure 1a-d shows identified UA forms. From a quick glance, it is evident that actual UA systems mirror the qualities outlined in sections 3.1 and 3.2: conditioned spaces have high capital inputs but reduced chances of ambient resource losses, while the nonconditioned spaces are lower intensity in terms of capital inputs and operational energy, but with diminished ability to minimize resource losses.

\subsection{Predicted attributes of urban agriculture types}

Figure $2 \mathrm{a}-\mathrm{c}$ outlines a comparison of the material and energy needs of ground-based-non-conditioned, ground-based-conditioned, building-integrated-non-conditioned, and building-
Fig. 1 a Ground-based-nonconditioned, b ground-basedconditioned, $\mathbf{c}$ buildingintegrated-non-conditioned, and $\mathbf{d}$ building-integrated-conditioned systems in the Northeastern USA. First author's own photographs

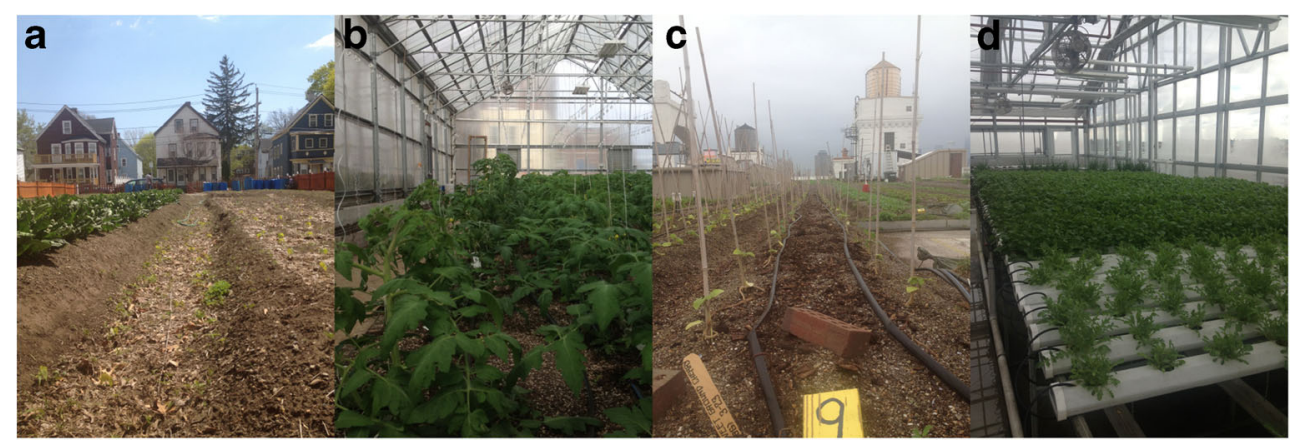



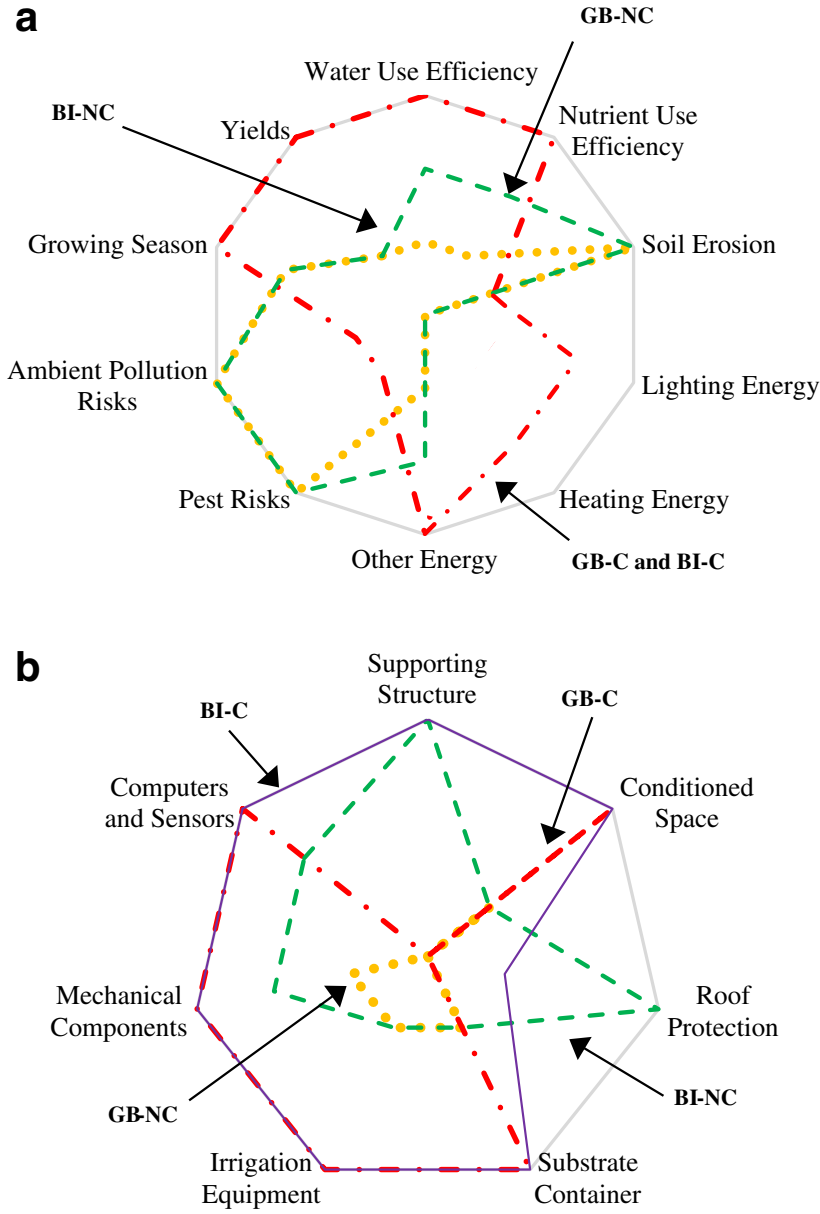

C

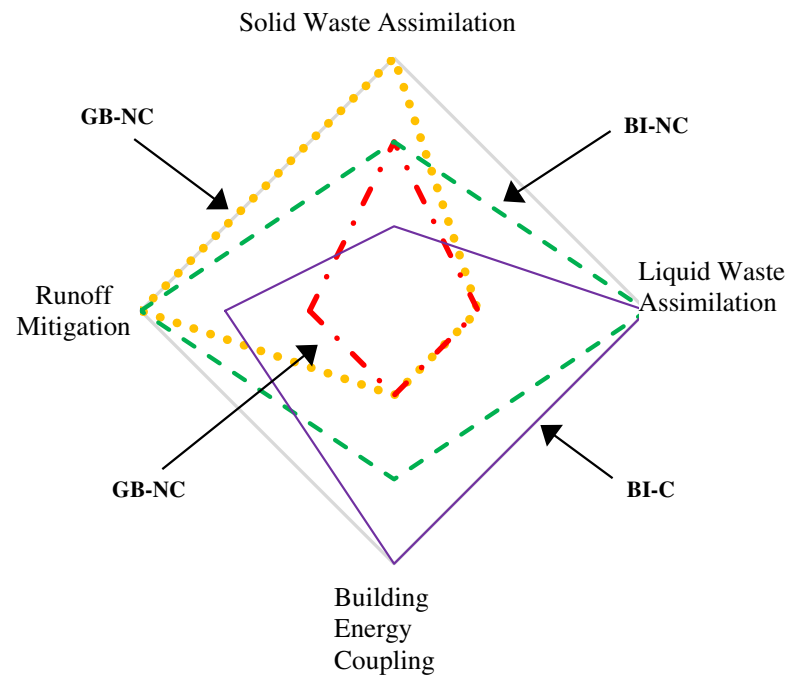

Fig. 2 a Operational characteristics, b capital inputs, and c urban symbiosis potential for ground-based-non-conditioned (GB-NC), groundbased-conditioned (GB-C), building-integrated-non-conditioned (BI-NC), and building-integrated-conditioned (BI-C) system. Note that in (a) conditioned types can have a large operational energy inputs, though this might be contingent on the climate and latitude, which would affect the amount of external energy to supply lighting and heating. Comparisons based on the site visit to an urban farm in 2015, the results of SanyéMengual et al. $(2015 b, c)$ and the findings of Kulat et al. integrated-conditioned UA types based on our cursory analysis, and Table 2 provides deeper details about these properties. Indicators are grouped into three broad categories covering operating characteristics (efficiency of supply use, external energy inputs, potential for crop losses, yields, and growing season length), capital inputs (typical equipment and structures), urban symbiosis potential (possible coupling with urban material and energy flows), and other general traits (economic and social motivators). This represents a very rough overview of predicted operating characteristics and material and energy needs of these systems given the same growing location, product, and agricultural practice (organic, conventional, mono cropping, etc.) Despite the elementary nature of this assessment, it highlights some divergent environmental aspects of the systems.

\subsubsection{Ground-based-non-conditioned systems}

In terms of operating characteristics, low resource use efficiency and yields due to dispersive losses of inputs and the potential for crop losses, countered by low external energy inputs, are expected. Capital inputs are also low (fencing, small tools, irrigation lines, and sometimes low-tech greenhouses for seedlings). Kulak et al.'s (2013) work on London allotment gardens confirms that the low nutrient and water efficiency of ground-based-non-conditioned UA, but lower capital inputs counteracted this, resulting in a reduced carbon footprint over conventional supply chains. Ground-basednon-conditioned UA also shows medium performance in the realm of urban symbiosis potential, whereby it can act as a significant assimilator of urban solid waste as compost, demonstrated in the UK (Edmondson et al. 2014) and Cuba (Hernandez et al. 2014) or additionally reduce stormwater runoff (Gliessman 2015). However, ground-based-nonconditioned is at a disadvantage to couple with the liquid waste or energy systems of the city, though site walkovers in NYC did demonstrate hookups with adjacent buildings to capture runoff from roofs for irrigation (see Grow NYC: http://tinyurl.com/q9cm4ba). Lastly, Fig. 1 also shows that the growing seasons and yields of the $\mathrm{NC}$ forms are less than their conditioned counterparts, which is evident when one considers that all the pictures were taken in May 2015 (except 1D which was captured in March 2015). Because of the low-tech nature and low yields of this type, it lends itself to non-profit operation (or supplemental income generation) and high levels of community engagement (nutritional education, after-school programs, etc.)

\subsubsection{Ground-based-conditioned systems}

Ground-based-conditioned contrasts with ground-based-nonconditioned in almost all indicators. Containment of growing medium and recycling makes for high efficiency of water and 


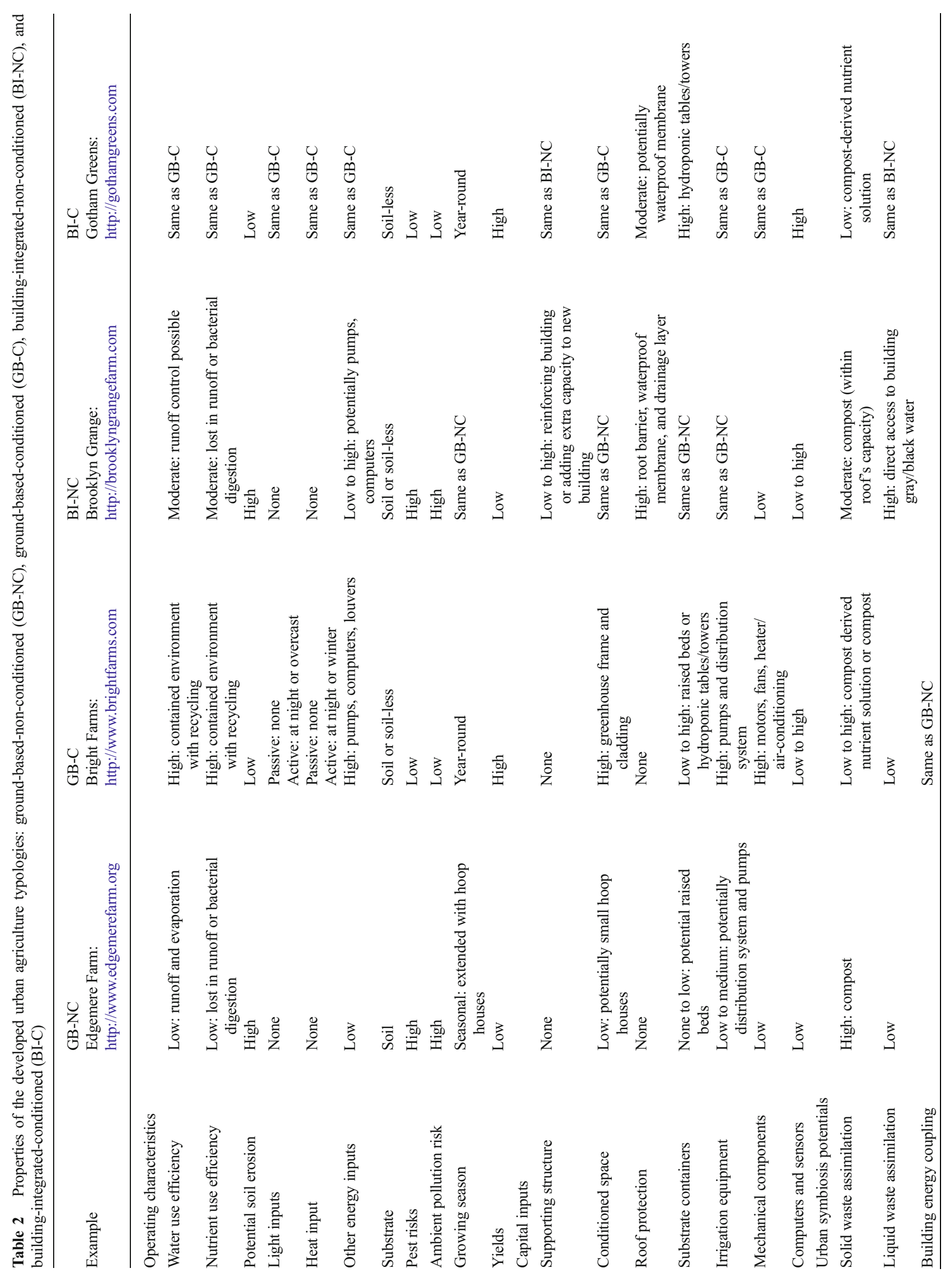


nutrients, concomitantly reducing potential losses from pests and weather. Conversely, operating energy is much higher to run equipment (pumps, heaters, mechanical louvers). Capital inputs are also high since ground-based-conditioned requires structural components, mechanical and irrigation equipment, and increasingly common, sensors and computers. The mix of high efficiency, high-energy inputs, and substantial built capital can have conflicting effects. Kulak's (2013) work in London shows that even using low-tech greenhouses without mechanical inputs or hydroponics can increase water efficiency, but the capital inputs actually caused UA strawberries to have higher embodied carbon impacts than a conventional supply chain.

In terms of operational energy, the importance of passive conditioned spaces (light and heat provided by solar) and active (light and heat provided through fuels or electricity) on environmental performance necessitates the need for two sub-categories in within the ground-based-conditioned type: active and passive. Active types have environmental impacts driven by operational energy, in line with QSAs of buildings, since the one-time impacts of constructing durable building components diminishes compared to the perennial energy inputs over the extended lifetime of the project (Scheuer et al. 2003). In contrast, capital inputs play a stronger role in the environmental performance of passive types, because operating inputs are relatively lower. The lack of studies comparing passive and active ground-based-conditioned operations makes it difficult to conclude on the tension between operational inputs and capital inputs.

Urban symbiosis potential for ground-based-conditioned is low compared to other UA types, since the primarily hydroponic nature of greenhouses complicates organic-waste recycling, while their detachment from buildings makes interactions with building and energy flows difficult. Site-specific storage capacity puts a cap on rainwater capture, further constricting potential symbiotic relationships with the city. Increased capital inputs mean that these farms typically operate to generate profit (see www.farmedhere.com or www. freightfarms.com), though non-profit projects with high levels of community engagement can also be found (see www. thefoodproject.org/dudley-greenhouse).

\subsubsection{Building-integrated-non-conditioned systems}

Building-integrated-non-conditioned mirrors the groundbased-non-conditioned in that its exposed environment lowers the efficiency of water and nutrients at the farm compared to conditioned UA, though building-integrated-non-conditioned could potentially recoup some losses at the building edge. Some building-integrated-non-conditioned systems actually utilize soil-less cultivation (perlite substrate) with high operational efficiency (Sanyé-Mengual et al. 2015c), though this practice is not yet pervasive in UA. Our interviews with 
rooftop farmers also revealed that soil erosion due to winds is a chronic issue. Looking at Fig. 1c, we can also see that though these systems have the potential for a considerable amount of capital inputs (irrigation networks, layers to protect roofing, sensors, and computers, etc.) and potentially structural buttressing.

The urban symbiosis potential of building-integrated-nonconditioned is very high as it can assimilate solid organic waste from the urban system (limited by load bearing capacity), directly affect building energy (providing insulation, increasing roof albedo, and capturing residual building energy to lengthen growing season) and water systems, and mitigate stormwater runoff. The numerous examples of green roofs in Table 1 attest to this with their positive contributions to building energy consumption (Bass and Baskaran 2003), stormwater mitigation (IBID), and also urban biodiversity (Gliessman 2015). Of course, these benefits are design-dependent, whereby less-intensive installations (e.g., raised beds) would show diminished building energy synergies compared to a building with the intensive UA. Lastly, buildingintegrated systems (non-conditioned and conditioned) create cultivable space out of the built urban form, providing a net increase in gross agricultural area; a benefit that the GB systems cannot accrue. Much like the ground-based-conditioned type, higher capital inputs generally restrict this type of farm to for-profit operation and lower community engagement in the examples that we have found (see www.brooklyngrange.com and www.greencitygrowers.com).

\subsubsection{Building-integrated-conditioned systems}

Building-integrated-conditioned systems are similar to the ground-based-conditioned systems in almost all aspects. Operational characteristics for these systems are identical to ground-based-conditioned farms, with the effect that passive and active sub-types must be included under this umbrella. Capital inputs are also very similar to the ground-basedconditioned type, except that structural reinforcement of the supporting building might be necessary. Urban symbiosis potential appears to be high since building-integratedconditioned can directly couple with the energy and water systems of its host building. Symbiosis potential is not as high as building-integrated-non-conditioned since the common usage of hydroponics (nearly ubiquitous in order to provide high enough efficiency to offset capital costs) limits waste assimilation abilities, while challenges to large-scale stormwater assimilation are also prevalent due to structural costs and on-site storage capacity. Sanyé-Mengual and colleagues' (2012) work on building-integrated-conditioned grown tomatoes shows that despite substantial capital inputs, these systems can have superior environmental performance over conventional methods, though this was a result of reduced packaging and distribution spoilage and less production efficiency. Again, the high capital and operating costs of these types of operations have largely limited them to for-profit operation with limited community engagement (see www.gothamgreens.com or www.lufa.com).

\section{Applying the UA taxonomy in future assessments}

The dearth of quantitative studies of UA environmental performance hampers testing of the developed taxonomy; however, we apply it to Sanyé-Mengual et al.'s (2015b, c) analysis of tomatoes grown on Barcelona rooftops. System 1 is a building-integrated -non-conditioned system using raised beds with soil substrate (Sanyé Mengual et al. 2015c). System 2 is a building-integrated-conditioned passive system using hydroponics (Sanyé Mengual et al. 2015b). Table 3 shows that the material and energy profiles align with the predictions of the taxonomy. Capital inputs are greater perunit output for the conditioned system, with the exception of wood, though wood has substantially lower embodied environmental burdens relative to the steel and aluminum in the conditioned system. This was echoed by the lower contribution of the cultivation system to total climate change impacts for system $1(<10 \%)$ relative to system $2(\sim 30 \%)$. Operational characteristics generally agreed with the UA systematics. Lower water demands contrast with higher energy demands for the system 1 (electricity for pumps); however, against our predictions, nutrient demands were higher for the conditioned system (particularly phosphorous), though the unaccounted nutrients in the soil and compost imported to system 2 might reverse this comparison. Yields are greater for the conditioned system $\left(\sim 25 \mathrm{~kg} / \mathrm{m}^{2}\right)$ than the nonconditioned $\left(13-14 \mathrm{~kg} / \mathrm{m}^{2}\right)$. Contributions to the climate change impacts of the two systems also agree with the systematics: system 1's impacts stemmed from operational inputs, while capital inputs had a larger influence on system 2 .

The previous example shows that our system, though simple, predicted the energy and material burdens of two UA systems, although it requires further tests of its robustness. However, after future verification, this taxonomy could emerge as a simple way to gauge the efficacy of UA as an urban design intervention to mitigate the environmental burdens of urban food provision. For instance the, urban designers looking to improve a city's environmental performance with UA could use the taxonomy to understand the various tradeoffs between the systems and answer questions about the appropriateness of technologies for a clime given the operational characteristics of a proposed system. With a larger base of studies to choose from, architects and designers could look at the types of produce that would fit within a local context given a chosen UA type, such as the choice to produce fruits over leafy greens in soil-based building-integratedconditioned systems considering the lower yields of the latter 
Table 3 Comparison of a building-integrated-nonconditioned operation (system 1) with a building-integratedconditioned (passive) operation (system 2)

\begin{tabular}{|c|c|c|c|}
\hline & Unit & $\begin{array}{l}\text { System 1: building-integrated- } \\
\text { non-conditioned (Sanyé-Mengual } \\
\text { et al. 2015c) }\end{array}$ & $\begin{array}{l}\text { System 2: building-integrated- } \\
\text { conditioned (Sanyé-Mengual } \\
\text { et al. 2015b) }\end{array}$ \\
\hline \multicolumn{4}{|l|}{ Capital inputs } \\
\hline Metals & $\mathrm{kg} / \mathrm{kg}$ tomato & 0.004 & 0.037 \\
\hline Aluminum & $\mathrm{kg} / \mathrm{kg}$ tomato & - & 0.003 \\
\hline Steel & $\mathrm{kg} / \mathrm{kg}$ tomato & 0.004 & 0.034 \\
\hline Biomaterials & $\mathrm{kg} / \mathrm{kg}$ tomato & 0.26 & - \\
\hline Wood & $\mathrm{kg} / \mathrm{kg}$ tomato & 0.25 & - \\
\hline Bamboo & $\mathrm{kg} / \mathrm{kg}$ tomato & 0.01 & - \\
\hline Plastics & $\mathrm{kg} / \mathrm{kg}$ tomato & 0.0002 & 0.017 \\
\hline LDPE & $\mathrm{kg} / \mathrm{kg}$ tomato & 0.0001 & 0.004 \\
\hline HDPE & $\mathrm{kg} / \mathrm{kg}$ tomato & - & 0.004 \\
\hline Polycarbonate & $\mathrm{kg} / \mathrm{kg}$ tomato & - & 0.006 \\
\hline Polyester & $\mathrm{kg} / \mathrm{kg}$ tomato & - & 0.0003 \\
\hline Polystyrene & $\mathrm{kg} / \mathrm{kg}$ tomato & - & 0.001 \\
\hline Polypropylene & $\mathrm{kg} / \mathrm{kg}$ tomato & 0.001 & - \\
\hline PVC & $\mathrm{kg} / \mathrm{kg}$ tomato & 0.0003 & 0.002 \\
\hline Aggregates & $\mathrm{kg} / \mathrm{kg}$ tomato & - & 0.02 \\
\hline Perlite & $\mathrm{kg} / \mathrm{kg}$ tomato & - & 0.02 \\
\hline \multicolumn{4}{|l|}{ Operational inputs } \\
\hline Water & $\mathrm{m}^{3} / \mathrm{kg}$ tomato & 0.5 & 0.03 \\
\hline Electricity & $\mathrm{kWh} / \mathrm{kg}$ tomato & 0.0002 & 0.04 \\
\hline Fertilizer $(\mathrm{N})$ & $\mathrm{g} / \mathrm{kg}$ tomato & 0.33 & 0.39 \\
\hline Fertilizer $\left(\mathrm{P}_{2} \mathrm{O}_{5}\right)$ & $\mathrm{g} / \mathrm{kg}$ tomato & 0.25 & 2.47 \\
\hline Fertilizer $\left(\mathrm{K}_{2} \mathrm{O}\right)$ & $\mathrm{g} / \mathrm{kg}$ tomato & 0.53 & 0.76 \\
\hline Compost & $\mathrm{g} / \mathrm{kg}$ tomato & 16 & - \\
\hline Soil & $\mathrm{g} / \mathrm{kg}$ tomato & 155 & - \\
\hline \multicolumn{4}{|l|}{ Outcomes } \\
\hline Yields & $\mathrm{kg}$ tomato $/ \mathrm{m}^{2}$ & $13-14$ & 25 \\
\hline Carbon footprint & $\begin{array}{l}\mathrm{kg} \mathrm{CO} \\
\text { tomato }\end{array}$ & $0.068-0.075$ & 0.22 \\
\hline $\begin{array}{l}\text { Cumulative energy } \\
\text { demand }\end{array}$ & $\mathrm{MJ} / \mathrm{kg}$ tomato & $1.14-1.26$ & 3.25 \\
\hline
\end{tabular}

$\mathrm{CO}_{2}$ eq. represents the equivalent amount of $\mathrm{CO}_{2}$ to have the same radiative forcing effect on the atmosphere as the greenhouse gases released during the production of the tomato. Cumulative energy demand is the total amount of energy embodied within the production of materials and energy directly consumed by the UA system. As can be seen, the capital inputs and energy demands of the conditioned system are higher. Water use is lower for the conditioned system. The energy and capital inputs for the conditioned system make it less favorable in terms of carbon footprint, despite the higher yields
(Sanyé-Mengual et al. 2015c). Next steps will involve building on the nascent QSAs that have shown the benefits and occasional shortcomings of UA in the environmental arena (Sanyé-Mengual et al. 2012, 2015b, c; Kulak et al. 2013). Future studies could employ the life cycle assessment (LCA) methodology used in the aforementioned study, material input per service, material flow accounting, or any other number of methods to assess the environmental sustainability of product systems.

The taxonomy aligns particularly well with LCA for a number of reasons. Firstly, LCA is a tool for comparing the environmental performance of different systems delivering a comparable function. The UA systematics here describe four UA types with markedly different attributes, facilitating LCA studies to compare four varied ways to produce food in cities that cover the broad spectrum of current UA forms. LCA is also methodologically mature; with its own international standards, a discipline-specific journal, significant industry application, and wide set of indicators to assess environmental performance (climate change, eutrophication, land occupation, toxicity, etc.) (Finnveden et al. 2009). 


\subsection{Application to studies of urban systems}

For researchers in urban systems, the growing interest in the environmental aspects of urban food procurement highlights the need for a vocabulary with which to organize dominant UA types. Moreover, the systematics underlying the vocabulary should be compatible with the perspective of urban systems researchers, that of urban metabolism.

Urban metabolism is the sum of material and energy produced or imported, as well as waste produced by a city in order to support its daily activities (Kennedy et al. 2007). It is a rapidly maturing area of study that continues to see growing interest from governments as a benchmarking method of urban environmental performance and methodology to quantify the environmental changes imparted by an urban design or policy decision (Kennedy et al. 2010; Clift et al. 2015). Studies of urban metabolism are typically an accounting exercise of the material and energy flows using bottom statistical data or top down national economic data, which can then be coupled with other methods to gauge urban environmental performance (Goldstein et al. 2013). This raises another benefit of LCA as an UA environmental assessment tool; it is seen as the natural choice by urban researchers to couple with studies of urban metabolism (Chester et al. 2012; Goldstein et al. 2013; Clift et al. 2015).

By using material and energy flows as an organizing principle, the UA taxonomy can be easily coordinated within metabolism assessments of neighborhoods or cities, helping to understand how an up-scaled UA system would interact with this metabolism to affect urban sustainability. Urban systems researchers have already looked at food and nutrient flows through cities, but prospective urban food production has not yet to be assessed, raising questions regarding UA's potential synergies (Sanyé-Mengual et al. 2014) and antagonisms with the larger urban environment (Pataki et al. 2009). The UA operational inputs, capital inputs, and urban symbiosis potential that inform the typology begin to highlight the interconnectedness of the urban system and the built environment. The indicators for solid and liquid waste assimilation align well with the numerous urban nutrient flow studies (Færge et al. 2001; Billen et al. 2008; Kalmykova et al. 2012), since the varied capacities of the UA systems to absorb these streams could cause important shifts to this metabolic aspect in an agriculturally productive city.

In general, the taxonomy would allow for a scaled up test of UA's environmental sustainability. A study could use satellite imagery and software to identify available space for ground-based UA within a case city (see Taylor and Lovell 2012). Geographic information systems software could also determine the suitability of buildings for UA incorporation based on age and design. The different material and energy flows associated with the chosen UA systems could then be framed within the larger urban metabolism to predict the material, energy, food, and waste regime of the altered system. Lastly, an LCA could estimate the environmental consequences of the new metabolism.

\subsection{Shortcomings of the proposed taxonomy}

One major disadvantage of the UA taxonomy is the small number of studies on which it relies and its anecdotal nature. Modern statistical methods that use significant sample populations to "bin"-like types are the norm for developing typologies. This was the method promoted by Kostrowicki (1977) in his foundational paper and has been employed by others in demarcating the different social and economic aims of UA (Dossa et al. 2011). Because of this shortcoming, the developed UA taxonomy is propositional in nature, able to evolve dynamically as new findings arise or be cast aside if its utility is ultimately low.

Another major caveat is the proposed taxonomy is singular in focus, ignoring the equally important socioeconomic characteristics of UA. There are many reasons to practice UA besides environmentally sustainable food production: leisure, community building, education, and food equity to name but a few (Sanyé-Mengual et al. 2015a; Thomaier et al. 2015). Decisions surrounding the implementation should equally weigh economic, social, and environmental outcomes where relevant though this might not always be the case. For instance, social and environmental performance might be secondary to economic returns in private business scenarios, or environmental and economic performance might be secondary to community building for a more socially oriented project.

It is also by viewing UA projects with competing motives (primarily economic vs. primarily social) through the lens of the proposed UA taxonomy that interesting observations might emerge. For instance, what are the environmental tradeoffs between high-efficiency, high-input economically driven building-integrated, conditioned projects, and low-efficiency, low-input socially focused ground-based, non-conditioned operations? How do the auspices of an UA project affect environmental performance? Can we generalize their material and energy throughputs of these operations? These questions remain largely unanswered to date and warrant exploration if UA is going to scale-up in cities, usually in concert with a larger environmental sustainability agenda. 


\section{Conclusion}

The environmental impacts from food consumed in cities are large, but cities have design tools to address them. However, urban design interventions should be adopted after due consideration of whether they actually achieve the expressed goal of increasing the sustainability of urban systems. This review shows that if UA is to promote on environmental grounds, then there remain a number of unanswered questions about the environmental performance of individual systems and less certainty regarding how an "edible city" would perform. Where solid evidence does exist, it has normally been performed on only one type of UA out of the panoply that exist, leaving a bric-a-brac picture of the larger environmental impacts of food production in cities. Significant differences in environmental performance of similar systems illustrate this well (Sanyé-Mengual et al. 2015c), and in at least one study, UA was not preferable to conventional supply chains for specific products and methods (Kulak et al. 2013). Though environmental benefits may very well be conferred to UA adopting cities, it would be wise to test these assertions deeper before committing to scaling-up.

This paper compliments earlier work to develop a structured understanding of UA's environmental integrity. We have developed a taxonomy of four general UA types based on their operating characteristics, capital inputs, and how they interact with urban systems. The types have significantly different behavior across these echoing the need for an organizing typology for and further assessment of UA. The proposed taxonomy is illustrative in its focus on important drivers behind the overall environmental performance of the UA systems and covers the majority of UA operating styles. The typologies differentiate between material and energy loading, but not how these are provisioned, and therefore, sub-types exist within the derived framework for "organic," "conventional," "integrated," or other cultivation techniques. Nonetheless, keeping product and location the same and combining the framework with environmental assessment methods would allow comparisons of the relative environmental performance of UA systems or conventional urban food supply chains. We have also outlined a path forward to apply the typology to a larger urban system to assess the environmental consequences of an altered urban metabolism through coupling with LCA and better understand whether UA is in fact a good environmental initiative. Such an appraisal is essential at this critical juncture where a fecundity of UA cases exist for analysis but expensive and potentially deleterious experiments at the urban scale have not yet come to fruition.

Society should not solely seek technological fixes to the environmental challenges feeding an increasingly urban planet will entail. Simple actions such as reducing animal product consumption, increasing seasonal and local consumption, and stymieing edible food waste will also have significant positive environmental benefits (Saxe 2014; Tilman and Clark 2014; Heller and Keoleian 2015). However, if cities can evolve to shoulder some of the burdens of their food provision, while concomitantly providing ancillary environmental, social, and economic benefits to the city with UA, then this strategy is worth pursuing.

\section{References}

Abdulkadir A, Dossa LH, Lompo DJ-P et al (2012) Characterization of urban and peri-urban agroecosystems in three West African cities. Int J Agric Sustain 10:289-314. doi:10.1080/14735903.2012. 663559

Ackerman K (2012) The potential for urban agriculture in New York City. New York, USA, New York

Angrill S, Farreny R, Gasol CM et al (2012) Environmental analysis of rainwater harvesting infrastructures in diffuse and compact urban models of Mediterranean climate. Int J Life Cycle Assess 17:2542. doi:10.1007/s11367-011-0330-6

Antisari L, Orsini F, Marchetti L et al (2015) Heavy metal accumulation in vegetables grown in urban gardens. Agron Sustain Dev 35:11381147

Astee LY, Kishnani NT (2010) Building integrated agriculture: utilising rooftops for sustainable food crop cultivation in Singapore. J Green Build 5:105-113. doi:10.3992/jgb.5.2.105

Awasthi MK, Pandey AK, Bundela PS, Khan J (2015) Co-composting of organic fraction of municipal solid waste mixed with different bulking waste: characterization of physicochemical parameters and microbial enzymatic dynamic. Bioresour Technol 182:200-207. doi:10.1016/j.biortech.2015.01.104

Barles S (2007) Feeding the city: food consumption and flow of nitrogen, Paris, 1801-1914. Sci Total Environ 375:48-58. doi:10.1016/j. scitotenv.2006.12.003

Bass B, Baskaran B (2003) Evaluating rooftop and vertical gardens as an adaptation strategy for urban areas.

Besthorn FH (2013) Vertical farming: social work and sustainable urban agriculture in an age of global food crises. Aust Soc Work 66:187203. doi: $10.1080 / 0312407 X .2012 .716448$

Billen G, Barles S, Garnier J et al (2008) The food-print of Paris: longterm reconstruction of the nitrogen flows imported into the city from its rural hinterland. Reg Environ Chang 9:13-24. doi:10.1007/ s10113-008-0051-y

Born B, Purcell M (2006) Avoiding the local trap: scale and food systems in planning research. J Plan Educ Res 26:195-207. doi:10.1177/ 0739456X06291389

Brock B, Foeken D (2006) Urban horticulture for a better environment: a case study of Cotonou, Benin. Habitat Int 30:558-578. doi:10.1016/ j.habitatint.2005.02.001

Brunori G, Di Iacovo F (2014) Urban food security and landscape change: a demand-side approach. Landsc Res 1-17. doi:10.1080/ 01426397.2014.891725

Castleton HF, Stovin V, Beck SBM, Davison JB (2010) Green roofs; building energy savings and the potential for retrofit. Energy Build 42:1582-1591. doi:10.1016/j.enbuild.2010.05.004

Cerón-Palma I (2012) Strategies for sustainable urban ecosystems: introducing eco-innovation in buildings in Mexico and Spain. Universitat Autotonoma de Barcelona

Chester M, Pincetl S, Allenby B (2012) Avoiding unintended tradeoffs by integrating life-cycle impact assessment with urban metabolism. Curr Opin Environ Sustain 4:451-457. doi:10.1016/j.cosust.2012. 08.004 
City of Boston (2014) Article 89 made easy.

City of New York (2014) 2014 NYC community composting report.

Clift R, Druckman A, Christie I, et al. (2015) Urban metabolism: a review in the UK context.

Cofie OO, Agbottah S, Strauss M et al (2006) Solid-liquid separation of faecal sludge using drying beds in Ghana: implications for nutrient recycling in urban agriculture. Water Res 40:75-82. doi:10.1016/j. watres.2005.10.023

Cohen N, Reynolds K, Sanghvi R (2012) 5 borough farm. New York

Davis J, Sonesson U, Baumgartner DU, Nemecek T (2010) Environmental impact of four meals with different protein sources: case studies in Spain and Sweden. Food Res Int 43:1874-1884. doi: 10.1016/j.foodres.2009.08.017

Davis AS, Hill JD, Chase CA et al (2012) Increasing cropping system diversity balances productivity, profitability and environmental health. PLoS One 7:e47149. doi:10.1371/journal.pone.0047149

Dearing JA, Wang R, Zhang K et al (2014) Safe and just operating spaces for regional social-ecological systems. Glob Environ Chang 28: 227-238. doi:10.1016/j.gloenvcha.2014.06.012

Decker EH, Elliott S, Smith FA et al (2000) Energy and material flow through the urban ecosystem. Annu Rev Energy Environ 25:685740. doi:10.1146/annurev.energy.25.1.685

Delor M (2011) Current state of building-integrated agriculture, its energy benefits and comparison with green roofs - summary. Sheffield

Despommier D (2013) Farming up the city: the rise of urban vertical farms. Trends Biotechnol 31:388-9. doi:10.1016/j.tibtech.2013.03. 008

Dickie G (2014) Q\&A: inside the world's largest indoor farm. In: Natl. Geogr. Mag. http://news.nationalgeographic.com/news/2014/07/ 140717-japan-largest-indoor-plant-factory-food/. Accessed 14 Nov 2015

Dossa LH, Abdulkadir A, Amadou $\mathrm{H}$ et al (2011) Exploring the diversity of urban and peri-urban agricultural systems in Sudano-Sahelian West Africa: an attempt towards a regional typology. Landsc Urban Plan 102:197-206. doi:10.1016/j.landurbplan.2011.04.005

Drechsel P, Dongus S (2009) Dynamics and sustainability of urban agriculture: examples from sub-Saharan Africa. Sustain Sci 5:69-78. doi:10.1007/s11625-009-0097-x

Edjabou LD, Smed S (2013) The effect of using consumption taxes on foods to promote climate friendly diets - the case of Denmark. Food Policy 39:84-96. doi:10.1016/j.foodpol.2012.12.004

Edmondson JL, Davies ZG, Gaston KJ, Leake JR (2014) Urban cultivation in allotments maintains soil qualities adversely affected by conventional agriculture. J Appl Ecol 51:880-889. doi:10.1111/13652664.12254

Edwards-Jones G, Milà i Canals L, Hounsome N et al (2008) Testing the assertion that "local food is best": the challenges of an evidencebased approach. Trends Food Sci Technol 19:265-274. doi:10. 1016/j.tifs.2008.01.008

Emilsson T, Czemiel Berndtsson J, Mattsson JE, Rolf K (2007) Effect of using conventional and controlled release fertiliser on nutrient runoff from various vegetated roof systems. Ecol Eng 29:260-271. doi:10. 1016/j.ecoleng.2006.01.001

Færge J, Magid J, Penning de Vries FWT (2001) Urban nutrient balance for Bangkok. Ecol Modell 139:63-74. doi:10.1016/S0304-3800(01) 00233-2

FAO (2006) Livestock's long shadow. Rome, IT

FAO (2011a) "Energy smart" food for people and climate.

FAO (2011b) Global food losses and food waste - extent, causes and prevention. Rome, IT

FAO (2013) Food waste footprint —impacts on natural resources - summary report.

Finnveden G, Hauschild MZ, Ekvall T et al (2009) Recent developments in life cycle assessment. J Environ Manage 91:1-21. doi:10.1016/j. jenvman.2009.06.018
Fioretti R, Palla a., Lanza LG, Principi P (2010) Green roof energy and water related performance in the Mediterranean climate. Build Environ 45:1890-1904. doi:10.1016/j.buildenv.2010.03.001

Five Borough Farm (2014) Urban agriculture in New York City. http:// www.fiveboroughfarm.org/urban-agriculture/. Accessed 23 Mar 2015

Foley JA, Ramankutty N, Brauman KA et al (2011) Solutions for a cultivated planet. Nature 478:337-42. doi:10.1038/nature10452

Forman R (2014) Urban ecology: science of cities. Cambridge University Press, Cambridge

Gliessman S (2015) Agroecology: the ecology of sustainable food systems, 3rd edn. CRC Press, Boca Raton

Goldstein B, Birkved M, Quitzau M-B, Hauschild M (2013) Quantification of urban metabolism through coupling with the life cycle assessment framework: concept development and case study. Environ Res Lett 8:1-14

Grard BJ-P, Bel N, Marchal N et al (2015) Recycling urban waste as possible use for rooftop vegetable garden. Futur. Food J. Food. Agric Soc 3:21-34

Green Home NYC (2011) Arbor house. http:/greenhomenyc.org/ building/arbor-house/. Accessed 15 Nov 2015

Grewal SS, Grewal PS (2012) Can cities become self-reliant in food? Cities 29:1-11. doi:10.1016/j.cities.2011.06.003

Grubler A, Bai X, Buettner T et al (2012) Chapter 18-urban energy systems. Global Energy Assessment - Toward a Sustainable Future. Cambridge University Press, Cambridge, UK and New York, NY, USA and the International Institute for Applied Systems Analysis, Laxenburg, Austria, In, pp 1307-1400

Haberman D, Gillies L, Canter A et al (2014) The potential of urban agriculture in Montréal: a quantitative assessment. ISPRS Int J Geo-Inf 3:1101-1117. doi:10.3390/ijgi3031101

Hampwaye G (2013) Benefits of urban agriculture: reality or illusion? Geoforum 49:R7-R8. doi:10.1016/j.geoforum.2013.03.008

Hara Y, Tsuchiya K, Matsuda H et al (2013) Quantitative assessment of the Japanese "local production for local consumption" movement: a case study of growth of vegetables in the Osaka City region. Sustain Sci 8:515-527. doi:10.1007/s11625-012-0198-9

Hargreaves JC, Adl MS, Warman PR (2008) A review of the use of composted municipal solid waste in agriculture. Agric Ecosyst Environ 123:1-14

Havaligi N (2011) The economic, social and political elements of climate change. 99-112. doi: 10.1007/978-3-642-14776-0

Heller MC, Keoleian GA (2015) Greenhouse Gas emission estimates of U.S. dietary choices and food loss. J Ind Ecol 19:391-401. doi:10. 1111 jiec. 12174

Hernandez OL, Calderín A, Huelva R, et al. (2014) Humic substances from vermicompost enhance urban lettuce production. Agron Sustain Dev 225-232. doi:10.1007/s13593-014-0221-x

Hoffman R (2007) Vegetated roof systems: design, productivity, retention, habitat and sustainability in green roof and eco-roof technology.

IPCC (2014a) IPCC 5th Assessment Report, Working Group III, chapter 1: introductory chapter.

IPCC (2014b) IPCC 5th Assessment Report, Working Group II, chapter 8: urban areas.

Jacobi P, Amend J, Kiango S (2000) City case study Dar es Salaam urban agriculture in Dar es Salaam: providing an indispensable part of the diet. In: Bakker N (ed) Growing cities, growing food: urban agriculture on the policy agenda. German Foundation for International Development, Feldafing, pp 257-283

Jaffal I, Ouldboukhitine S-E, Belarbi R (2012) A comprehensive study of the impact of green roofs on building energy performance. Renew Energy 43:157-164. doi:10.1016/j.renene.2011.12.004

Jansson $\AA$ (2013) Reaching for a sustainable, resilient urban future using the lens of ecosystem services. Ecol Econ 86:285-291. doi:10.1016/ j.ecolecon.2012.06.013 
Jim CY, Chen WY (2009) Ecosystem services and valuation of urban forests in China. Cities 26:187-194. doi:10.1016/j.cities.2009.03. 003

Kalmykova Y, Harder R, Borgestedt H, Svanäng I (2012) Pathways and management of phosphorus in urban areas. J Ind Ecol 16:928-939. doi:10.1111/j.1530-9290.2012.00541.x

Kennedy C (2012) Comment on article "is there a metabolism of an urban ecosystem?" by Golubiewski. Ambio 41:765-6. doi:10.1007/ s13280-012-0314-1, discussion 767-8

Kennedy C, Cuddihy J, Engel-yan J (2007) The changing metabolism of cities. J Ind Ecol 11:43-59. doi:10.1162/jie.2007.1107

Kennedy C, Pincetl S, Bunje P (2010) The study of urban metabolism and its applications to urban planning and design. Environ Pollut 159: 1965-73. doi:10.1016/j.envpol.2010.10.022

Khai NM, Ha PQ, Öborn I (2007) Nutrient flows in small-scale periurban vegetable farming systems in Southeast Asia - a case study in Hanoi. Agric Ecosyst Environ 122:192-202. doi:10.1016/j.agee. 2007.01.003

Knowd I, Mason D (2006) Urban agriculture: the new frontier. In: Planning for food seminar. pp 1-22

Koc M, Macrae R, Mougeot LJA, Welsh J (1999) For hunger-proof cities sustainable urban food systems. International Development Research Centre, Ottawa

Kokogiannakis G, Tietje A, Darkwa J (2011) The role of green roofs on reducing heating and cooling loads: a database across Chinese climates. Procedia Environ Sci 11:604-610. doi:10.1016/j.proenv. 2011.12.094

Komilis D, Evangelou A, Giannakis G, Lymperis C (2012) Revisiting the elemental composition and the calorific value of the organic fraction of municipal solid wastes. Waste Manag 32:372-381. doi:10.1016/j. wasman.2011.10.034

Kostrowicki J (1977) Agricultural typology concept and method. Agric Syst 2:33-45. doi:10.1016/0308-521X(77)90015-4

Krausmann F, Gingrich S, Eisenmenger N et al (2009) Growth in global materials use, GDP and population during the 20th century. Ecol Econ 68:2696-2705. doi:10.1016/j.ecolecon.2009.05.007

Kulak M, Graves A, Chatterton J (2013) Reducing greenhouse gas emissions with urban agriculture: a life cycle assessment perspective. Landsc Urban Plan 111:68-78. doi:10.1016/j.landurbplan.2012.11. 007

La Roche P, Berardi U (2014) Comfort and energy savings with active green roofs. Energy Build 82:492-504. doi:10.1016/j.enbuild.2014. 07.055

Larsen T, Peters I, Alder A, et al. (2001) The toilet for sustainable waste management. Environ Sci Technol 193 A-197 A.

Lee-Smith D, Prain G (2006) Understanding the links between agriculture and health: urban agriculture and health. Focus 13 May:1-2

Li Y, Babcock RW (2014) Green roofs against pollution and climate change. A review. Agron Sustain Dev 695-705. doi: 10.1007/ s13593-014-0230-9

Li D, Bou-Zeid E, Oppenheimer M (2014) The effectiveness of cool and green roofs as urban heat island mitigation strategies. Environ Res Lett 9:055002. doi:10.1088/1748-9326/9/5/055002

Liebman MB, Jonasson OJ, Wiese RN (2011) The urban stormwater farm. Water Sci Technol 64:239. doi:10.2166/wst.2011.182

Luckett K (2009) Green roof construction and maintenance. McGraw Hill, New York

Lufa Farms (2014) Lufa Farms. www.lufa.com. Accessed 15 Nov 2015

Marks P (2014) Vertical farms sprouting all over the world. In: New Sci. https:/www.newscientist.com/article/mg22129524-100-verticalfarms-sprouting-all-over-the-world/. Accessed 14 Nov 2015

Martellozzo F, Landry J-S, Plouffe D et al (2014) Urban agriculture: a global analysis of the space constraint to meet urban vegetable demand. Environ Res Lett 9:064025. doi:10.1088/1748-9326/9/6/ 064025
McClintock N, Cooper J, Khandeshi S (2013) Assessing the potential contribution of vacant land to urban vegetable production and consumption in Oakland, California. Landsc Urban Plan 111:46-58. doi:10.1016/j.landurbplan.2012.12.009

Meier T, Christen O (2013) Environmental impacts of dietary recommendations and dietary styles: Germany as an example. Environ Sci Technol 47:877-88. doi:10.1021/es302152v

Meuser H (2010) Introduction. In: Alloway B, Trevors J (eds) Contaminated urban soils. Springer Netherlands, Dordrecht, pp 1-3

Miljøministreriet (2005) Risikovurdering af anvendelse af lokalt opsamlet fæces i private havebrug. Copenhagen

Morée AL, Beusen AHW, Bouwman AF, Willems WJ (2013) Exploring global nitrogen and phosphorus flows in urban wastes during the twentieth century. Global Biogeochem Cycles 27:836-846. doi:10. $1002 / \mathrm{gbc} .20072$

Mougeot L (1994) Introduction. In: Egziabher AG, Lee-Smith D, Maxwell DG, Memon PA, Mougeot LJA, Sawio CJ (eds) Cities feeding people. International Development Research Center, Ottawa, pp 1-23

Nelkin J, Caplow T (2008) Sustainable controlled environment agriculture for urban areas. Acta Hortic 801:449-455. doi:10.17660/ ActaHortic.2008.801.48

Oberndorfer E, Lundholm J, Bass B et al (2007) Green roofs as urban ecosystems: ecological structures, functions, and services. Bioscience 57:823. doi:10.1641/B571005

Orsini F, Kahane R, Nono-Womdim R, Gianquinto G (2013) Urban agriculture in the developing world: a review. Agron Sustain Dev 33: 695-720. doi:10.1007/s13593-013-0143-Z

Orsini F, Gasperi D, Marchetti L, et al. (2014) Exploring the production capacity of rooftop gardens (RTGs) in urban agriculture: the potential impact on food and nutrition security, biodiversity and other ecosystem services in the city of Bologna. Food Secur 781-792. doi:10.1007/s12571-014-0389-6

Pataki DE, Emmi PC, Forster CB et al (2009) An integrated approach to improving fossil fuel emissions scenarios with urban ecosystem studies. Ecol Complex 6:1-14. doi:10.1016/j.ecocom.2008.09.003

Pataki DE, Carreiro MM, Cherrier J et al (2011) Coupling biogeochemical cycles in urban environments: ecosystem services, green solutions, and misconceptions. Ecol Soc Am 9:27-36

Pearson LJ, Pearson L, Pearson CJ (2010) Sustainable urban agriculture: stock take and opportunities. Int J Agric Sustain 8:7-19. doi:10. 3763/ijas.2009.0468

Perrin A, Basset-Mens C, Huat J, Yehouessi W (2015) High environmental risk and low yield of urban tomato gardens in Benin. Agron Sustain Dev 305-315. doi:10.1007/s13593-014-0241-6

Philips A (2013) Designing urban agriculture. Wiley

Pincetl S, Chester M, Circella G et al (2014) Enabling future sustainability transitions. J Ind Ecol 18:871-882. doi:10.1111/jiec.12144

Qadir M, Wichelns D, Raschid-Sally L et al (2010) The challenges of wastewater irrigation in developing countries. Agric Water Manag 97:561-568. doi:10.1016/j.agwat.2008.11.004

Qiu G, Li H, Zhang Q et al (2013) Effects of evapotranspiration on mitigation of urban temperature by vegetation and urban agriculture. J Integr Agric 12:1307-1315. doi:10.1016/S2095-3119(13)60543-2

Reidsma P, Tekelenburg T, van den Berg M, Alkemade R (2006) Impacts of land-use change on biodiversity: an assessment of agricultural biodiversity in the European Union. Agric Ecosyst Environ 114: 86-102. doi:10.1016/j.agee.2005.11.026

Roy P, Orikasa T, Thammawong M et al (2012) Life cycle of meats: an opportunity to abate the greenhouse gas emission from meat industry in Japan. J Environ Manage 93:218-24. doi:10.1016/j.jenvman. 2011.09.017

RUAF (2006) Cities farming for the future. International Development Research Center, Ottawa

Ruma MM, Sheikh AU (2010) Reuse of wastewater in urban farming and urban planning implications in Katsina metropolis, Nigeria. African J Environ Technol 4:28-33 
Sanyé-Mengual E, Cerón-Palma I, Oliver-Solà J, et al. (2012) Environmental analysis of the logistics of agricultural products from roof top greenhouses in Mediterranean urban areas. J Sci Food Agric 100-109. doi:10.1002/jsfa.5736

Sanyé-Mengual E, Llorach-Masana P, Sanjuan-Delmas D, et al. (2014) The ICTA-ICP Rooftop Greenhouse Lab (RTG-Lab): closing metabolic flows (energy, water, CO2) through integrated rooftop greenhouses. In: Finding spaces for productive cities. Proceedings of the 6th AESOP Sustainable Food Planning conference.

Sanyé-Mengual E, Anguelovski I, Oliver-Solà J, et al. (2015a) Resolving differing stakeholder perceptions of urban rooftop farming in Mediterranean cities: promoting food production as a driver for innovative forms of urban agriculture. Agric Human Values 1-20. doi: 10.1007/s10460-015-9594-y

Sanyé-Mengual E, Oliver J, Montero JI et al (2015b) An environmental and economic life cycle assessment of rooftop greenhouse (RTG) implementation in Barcelona, Spain. Assessing new forms of urban agriculture from the greenhouse structure to the final product level. Int J Life Cycle Assess 20:350-366. doi:10.1007/s11367-014-08369

Sanyé-Mengual E, Orsini F, Oliver-solà J et al (2015c) Techniques and crops for efficient rooftop gardens in Bologna, Italy. Agron Sustain Dev 35:1477-1488. doi:10.1007/s13593-015-0331-0

Saxe H (2014) The new Nordic diet is an effective tool in environmental protection: it reduces the associated socioeconomic cost of diets. Am J Clin Nutr 99:1117-1125. doi:10.3945/ajen.113.066746

Scheuer C, Keoleian GA, Reppe P (2003) Life cycle energy and environmental performance of a new university building: modeling challenges and design implications. Energy Build 35:1049-1064. doi: 10.1016/S0378-7788(03)00066-5

Sida (2003) Annotated bibliography of urban agriculture. Stockholm

Smil V (2013) Making the modern world: materials and dematerialization. Wiley

Smit J, Nasr J, Ratta A (2001) Urban agriculture - food, jobs and sustainable cities. In: Cities that feed themselves. The Urban Agriculture Network, Inc.

Specht K, Siebert R, Hartmann I, et al. (2013) Urban agriculture of the future: an overview of sustainability aspects of food production in and on buildings. Agric Human Values. doi: 10.1007/s10460-0139448-4

Steffen W, Richardson K, Rockström J, et al. (2015) Planetary boundaries: guiding human development on a changing planet. Science (80-). doi:10.1126/science.1259855

Stoessel F, Juraske R, Pfister S, Hellweg S (2012) Life cycle inventory and carbon and water foodprint of fruits and vegetables: application to a swiss retailer. Environ Sci Technol 46:3253-3262. doi:10.1021/ es2030577

Stringer L (2015) New York restaurants scramble for alternatives after city bans foam packaging. Guard.

Taylor JR, Lovell ST (2012) Mapping public and private spaces of urban agriculture in Chicago through the analysis of high-resolution aerial images in Google Earth. Landsc Urban Plan 108:57-70. doi:10. 1016/j.landurbplan.2012.08.001

Thomaier S, Specht K, Henckel D et al (2015) Farming in and on urban buildings: present practice and specific novelties of zero-acreage farming (ZFarming). Renew Agric Food Syst 30:43-54. doi:10. $1017 /$ S1742170514000143

Tilman D, Clark M (2014) Global diets link environmental sustainability and human health. Nature. doi: 10.1038/nature13959

Tilman D, Balzer C, Hill J, Befort BL (2011) Global food demand and the sustainable intensification of agriculture. Proc Natl Acad Sci U S A 108:20260-4. doi:10.1073/pnas.1116437108

Vejre H (2012) Working group 1: urban agriculture definitions and common agrarian policy. In: Lohrberg F, Timpe A (eds) COST action urban agriculture europe: documentation 1st working group meeting. pp 11-16

Von Zabeltitz C (2011) Integrated greenhouse systems for mild climates. Springer, Heidelberg

Wong NH, Tay SF, Wong R et al (2003) Life cycle cost analysis of rooftop gardens in Singapore. Build Environ 38:499-509. doi:10. 1016/S0360-1323(02)00131-2

World Bank (2013) Capital for the future. Washington, DC

Yang J, Yu Q, Gong P (2008) Quantifying air pollution removal by green roofs in Chicago. Atmos Environ 42:7266-7273. doi:10.1016/j. atmosenv.2008.07.003 